\title{
Human Resource Management Practices and the perceived Hospital performance: The mediating role of Intellectual Capital.
} Author

Raghda Abulsaoud Ahmed Younis

Lecturer of Business Administration-Faculty of Commerce Cairo university

E-mail :Raghdauniv@cu.edu.eg

\begin{abstract}
An extensive literature review covered two perspectives, namely, 'Human resource management (HRM) predict organizational performance' (OP), and intellectual capital predicts organizational performance. However, the linkage of "whether a bundle of good HR practices facilitates intellectual capital, which then leads to better organizational performance" is still a research gap.

The purpose of this paper is to examine the impact of high performance work system ( HPWS) on perceived hospital performance. In addition, this paper interesting in examining the mediating role of Human, Social and Organization capital in the hypothesized model.

Data were collected from $198 \mathrm{HR}$ managers working in private healthcare organizations in great Cairo. The analytical method used to empirically test the hypotheses is the structural equation modeling technique using AMOS( V.22). The two steps are the assessment of the outer model and the assessment of the inner model.

Results found that only human and social capital mediates HR practices-organizational performance relationship. This study is considered one of the first studies that examine the mediating role Human, Social and organization capital on the relationship between 'good HR practices' and organizational performance in private healthcare sector within Arab countries.
\end{abstract}

KEYWORDS: High- performance work system , Intellectual capital, Healthcare organizations. 


\section{Introduction}

In the competition era depending on the knowledge and skills, no organization could success without human resources capabilities in order to achieve sustainability. Organizations need to adopt HR practices in order to manage their valuable and talented employees (Chahal \& Jyoti, 2016). High-performance work system has been the interest of scholars over the last 20 years (Boxall \& Macky, 2009), it has been seen added advantage for firms and achieve better outcomes (Shin \& Konrad, 2014).Otherwise, there is a growing interest in studying the construct of Intellectual Capital (IC) as it should be involved within organization strategy in order to achieve better outcomes (e.g Nahapiet \& Ghoshal, 1998). In knowledge -intensive firms such as: Health Care, where the value accrues from high-quality services provided by medical staff as result of collective and synergetic human efforts (Yang \& Lin, 2009). Therefore, effective HR system may facilitate the aggregation of an Intellectual capital at the organizational -level in the challenging times.

Because every firm adopts its own practices, Deciding the good HR practices that achieve better outcomes is still problematic (Torre \& Solari, 2011). However, this study devoted to the investigation of good HR practices namely, high-performance work system (HPWS). It is our focus that IC is aggregated over time through the impact of daily investments in best bundle of HRM practices.

An extensive literature review covered two perspectives, namely, 'Human resource management (HRM) predict organizational performance' (OP) (e.g. Delaney \& Huselid, 1996), and intellectual capital predicts organizational performance (eg.Subramaniam \& Youndt, 2005). However, the linkage of "whether a bundle of good HR practices facilitates IC , which in turn, leads to better business performance" is still a research gap. especially, in healthcare organizations. where OP depending on the synergic impact resulting from the sum of 
skills, knowledge and professional's capabilities. Accordingly, this study attempts to answers the following questions:

(1) Can HPWS as a bundle of HR practices explain the multidimensional view of intellectual capital? (2) Do human, social and organizational capital can best explain perceived organizational performance? (3) Can intellectual capital 's dimensions mediate the relationship between HPWS and perceived organizational performance?

The context of our study -The Private healthcare hospitals in Arab Republic of Egypt - added value to the literature for two major reasons. First, hospitals or health care organizations rely, primarily, on a highly knowledgeable staff ex. Nurses, Medical staff. Thus, this sector would be a valuable sector for collecting the research data related to the significance of IC dimensions. Second, Private hospitals much care about their investments and performance. Thereby, investments in good HR practices would be observable.

\section{Theoretical background}

\section{High - performance work systems}

HR literature concern about HR practices that can lead to organization performance. HPWS was one of their concerns, sometimes called high-performance HR practices, which are composed of different set of practices that improve business performance (Chahal \& Jyoti, 2016;Ugheoke, et al., 2015). HPWS is viewed as a system of interconnected and reinforcing HR practices including performance appraisal, selective staffing, clear job description and training. this system aims to attract, acquire, manage, retain workers (Wang \& Chen, 2013; Way, 2002), especially high-quality human capital (García-Chas, Neira-Fontela, \& Varela-Neira, 2016). such practices enable employees to exercise decision making and possess superior abilities, in order to achieve continuous improvement (Way, 2002). 
Compared with HR practices, HPWS has been shown to be effective in encouraging employee to recognize organizational goals and work hard to achieve it (Chahal \& Jyoti, 2016). Such systems that stimulate the interaction between management and labor (Aghazadeh \& Seyedian, 2004) help firms to manage their employees and promoting good firm performance (Qiao, Wang, \& Wei, 2015). Empirical studies have shown that systematical implementation of HPWS as a bundle (which mean recognizing HR practices via a coherent work system) is the key factor to achieve positive outcomes (Wallner, Menrad, \& Thurner, 2012) and produce system-wide effect (Ingvaldsen, Johansen, \& Aarlott, 2014).

\section{Intellectual capital}

Although, IC is the interest of various researchers, there is a variety in conceptualizing and developing a preciously definition for the term. Brooking (1996) defined intellectual capital as combined intangible assets. Stewart (1997) conceptualized IC as an organization's collective brainpower or useful knowledge. These definitions aren't enough for identifying the truly value added by this term, they are only capturing the term from static view- the available knowledge or intangible assets in the organization- (Rossi, Cricelli, Grimaldi, \& Greco, 2016).

Other researchers identify the term as the outcome of the knowledge processes in the corporate. For example ; Hall (1992) view IC as transforming the organization's resources into intangible assets having extra - added value. Alipour ( 2012) viewed the construct as the difference between organization's book-value and organization's market - value , which can also be stated in its financial reports. Riahi-Belkaoui (2003). revealed that IC should be recognized as the value of talented people in the organization. According to these interpretations, IC - from the dynamic view - could be presented as deployment of 
intangible assets and their interaction to produce value directly and indirectly (Rossi, Cricelli, Grimaldi, \& Greco, 2016). As well as, it is the collective knowledge in organization utilized for achieving competitive advantage (Wang \& Chen, 2013). Intellectual capital is also defined as the sum of information, knowledge, know-how, and experience held by workers in firm to create a competitive advantage (Dženopoljac, Janoševic, \& Bontis, 2016).

From the former definitions, the author interprets IC as the current and potential intangible assets that create sustainable value for the organization. In addition, The obvious illustrations assert the importance of IC for companies and encourage for conducting more researches for IC- OP relationship.

Main Components of IC.

The author considered three main dimensions as it has been reviewed by researchers within healthcare sector (Yang \& Lin, 2009), which are: human capital (HC), structural capital or organizational capital(OC) and social capital(SC).

Simply, $\mathrm{HC}$ relates to entire resources and assets related to a firm's workforce (Alipour, 2012). Human capital is the collective skills, abilities and knowledge embodied in the individuals working in a firm (Fu, 2013; Wang \& Chen, 2013; Asiaei \& Jusoh, 2015), i.e. the intelligence of organization members (Inkinen, 2015). In addition, Wang, et al. (2014) defined HC as the total individual's knowledge, competences, attitude, skills and experience. On the other hand, organization my face a main problem with human assets- they are hard to be owned by the organization-. Unfortunately, the employees' departure means the possibility for losing some of company's power or knowledge ,thus competitive advantage (Bontis, Keow , \& Richardson, 2000). The company must have the capability to aquire new fresh knowledge assets and retain the best ones for achieving continuous advantage to the company. 
Whereas, SC is 'invisible power" relates to the actual and potential knowledge embedded within significant network of relationships among individuals, organizations or community members (Jiang \& Liu, 2015;Inkinen, 2015). specially, informal interactions among organization members (Asiaei \& Jusoh, 2015), which characterized by collaborative trusted environment in which knowledge flows freely (Youndt \& Snell, 2004). It has been approved that effective knowledge sharing contribute to improve learning capabilities that embedded in relationships between firm and its external stakeholders (Wang, Wang, \& Liang, 2014). For empirical limitations, This study focused only on the knowledge remain within the internal network of relationships among firm's people.

Regarding OC, it was defined as the institutionalized knowledge embedded and stored in the firm's proceduers, structure, system, notes and manuals (Fu, 2013; Youndt \& Snell, 2004; Inkinen, 2015). OC consists of all the non-human firms storehouses of knowledge in firms, belongs to the firms itself (Agostini, Nosella , \& Filippini, 2017). it can also be defined as the value of "what residue in the company when employees go home for the rest of the day (Bontis, Keow , \& Richardson , 2000).

Scholars agreed that conceptual separation of these three dimensions of IC is evident from how each aspect aggregates and disseminates knowledge differently (Subramaniam \& Youndt, 2005). A natural outcome of these differences is that each of these dimensions of intellectual capital requires unique kinds of investments (Youndt \& Snell, 2004) and has different influences on both organizational capabilities (Subramaniam \& Youndt, 2005) and performance (Andreeva \& Garanina , 2016).

Intellectual Capital can be considered as a valuable asset for any organization. It can play a significant role in the creating value process and for improving business performance (Rossi, Cricelli, Grimaldi, \& Greco, 2016). Intellectual capital - from the 
resource-based view-, is considered as a strategic, intangible asset that can positively influence the future of the organiztion (RiahiBelkaoui, 2003). Intellectual capital assets could take different forms such as; organizational values, internal relations, infomation, Knowledge , competence regarding the system, procedures, and relations with stakeholders (Rossi, Cricelli, Grimaldi, \& Greco, 2016). Various scholars suggested that IC effects positively the organizational financial performance and its market value ( Chen, Cheng, \& Hwang, 2005).

\section{HPWSs and IC}

HR managers tend to invest and develop the qualified employees ( i.e maximizing their human capital), and the main purpose of such investments is improving firm performance (Bontis, Crosson, \& Hulland, 2002). HPWSs have long been accepted as an effective way of fostering $\mathrm{HC}$ within firms. Since firms invest in employees but don't actually own them. thus, firms must apply methods to retain best employees and ensuring that they act in firm's interest (Snell \& Dean, 1992).

Studies have the link between intellectual capital dimensions and firm investments in specific HR practices. One of the most obvious methods used to enhance the pool of human capital is through people they acquire (Delaney \& Huselid, 1996). The organization needs to identify and attract superior professionals, and this can be achieved by HR practices such as: recruitment and comprehensive staffing practices that optimize the appropriate skills needed for organization development (Huselid, 1995; Fu, 2013; Wang \& Chen, 2013) .

A higher level of $\mathrm{HC}$ can also be obtained through extensive training. The ability to provide formal and informal training programs, such as on-the-job experience, may enrich the employees' knowledge and skills essential for firm success (Huselid, 1995; Snell \& Dean, 1992; Fu, 2013; Wang \& Chen, 2013;Delaney \& Huselid, 1996). Furthermore, The pool of 
skilled workers will be limited, if they are not effectively motivated (Delaney \& Huselid, 1996). workers would do more efforts into developing the job-related knowledge, if the rewards or incentives are related to the gaining and retaining of such knowledge (Fu, 2013; Wang \& Chen, 2013). Based on the above discussion, this paper expects that human capital stock will likely be affected by the implementation of of HPWSs.

H1. HPWSs have a positive impact on human capital.

Studies showed that HPWSs could contribute to organizational capital by different ways. First, implementing selective staffing through which new employees are selected according to the fit between their attributes and organization culture (Fu , 2013). second, organization could implement training programs through which new employees can become aware with the current organizational structure, procedures, values, systems and policies databases (Fu, 2013; Wang \& Chen, 2013). Third, Interactions among employees and through work-group - as an inherent aspect of HPWSs- is promoted to serve as a vital key for integrating and sharing knowledge within the firm (Nonaka, 1994). Thus, we expect that High performance work systems could provide the mechanisms for enhancing the development of organizational capital. Accordingly, the study developed the following hypothesis:

H2. HPWSs have a positive impact on organizational capital.

HRM practices could play a vital role in developing social relations among employees by enhancing the ability, motivation and opportunity for assessing one another's knowledge. scholars assert that HPWSs can play significant role in the development of a firm's social capital by motivating and expanding opportunities for social interactions between employees (Yang \& Lin, 2009). These interactions facilitate the development of friendships, confidence, and knowledge share. e.g practices such 
as extensive training and effective communications could enhance SC through expanding the interpersonal communication, expanding deep interactions and knowledge exchange (Yang \& Lin, 2009). Leana \& Buren (1999) revealed that selection and employment according to personnel - social interests and ability could improve organizational internal SC. On the basis of the above reasoning, we hypothesized the following:

H3. HPWSs have a positive impact on social capital.

\section{HPWSs and Organizational performance}

HPWS as a bundle of HR practices encourage and motivate workers to reinforce storing knowledge and Contributing to organizational performance. It is asserted in the literature that HR practices - as a bundle - are interconnected with each other to produce the synergistic effect on business performance (Chahal \& Jyoti, 2016).

There are several models in the Theoretical foundations described the causal link between HR practices and performance including the resource-based view and behavior theory. the Resource Based - view has been used to interpret how HRM can impact firm performance (Takeuchi, et al., 2007). some scholars argued that- due to the uncertainty in business environment- HPWS has a positive impact on organizational performance, through which employees generate superior outcomes, these outcomes are valuable and rare i.e intellectual capital, which in turn results in achieving superior indicators of firm performance (Way, 2002; Wang \& Chen, 2013).

the Behavioral theory is widely used as an example of the theory that aims to describe the causal link between human resource practices and organization performance through the AMO framework - ability , motivation and opportunity - (Shin \& Konrad, 2014;Cafferkey \& Dundon, 2015). Studies revealed insights into the effect of HPWS on 
work outcomes (Kalmi \& Kauhanen, 2008) considering it as the black box in the linkage between HPWS and business performance (García-Chas, et al., 2016). In summary, extensive literature examined the HRM and performance link (e.g.,.Delaney \& Huselid, 1996; Way ,2002; Arthur ,1994;Boxall \& Macky , 2009), However, limited studies examined this relationship in the health care sector (e.g Yang \& Lin, 2009). On the basis of the above reasoning, we hypothesized the following: H4. HPWSs have a positive impact on organizational performance.

\section{Intellectual capital and Organizational performance}

Human capital and OP: previous scholars discussed the effect of human capital on different aspects of performance, such as employee performance (Liao, Toya, Lepak, \& Hong, 2009) and innovation performance (Agostini, Nosella , \& Filippini, 2017). talented workers are likely have the ability to potentially enhance firm performance (Asiaei \& Jusoh, 2015), by increasing value to customers and decreasing operation and service delivery costs (Youndt \& Snell, 2004). For example, a study by Wang, Wang, \& Liang (2014) investigate the impact of human capital on OP within a sample of high- technology firms in China, the study found that human capital plays a significant role in enhancing both operational and financial performance. In addition, empirical findings showed that there are positive relationships between IC- including human capital - and firm performance (Kalkan, Bozkurt, \& Arman, 2014) (Gogan, Artene, Sarca, \& Draghici , 2016)

Social capital and $O P$ : the knowledge embedded within social networks i.e. the relationships among workers. These knowledge may enhance creativity and problem solving process. Furthermore, it tends to increase operation and service delivery quality. SC is more valuable when information and knowledge sharing flow easly within members, and this helps the firms to 
achieve higher productivity and competitive performance (Chia, Yahya, \& Yean, 2016). Additionally, however, social capital should improve organization performance, by reducing work costs, as a result of increasing the organization's information processing capacity (Asiaei \& Jusoh, 2015; Youndt \& Snell, 2004).

Organization capital and OP: Studies showed that organizational capital could have a positive outcome (Asiaei,2014), and others explain that relationship. for example, Wang (2010) discuss how organizational capital could facilitate innovative capabilities, providing knowledge system, avoiding repeating mistakes and sustaining knowledge. Another study by Youndt \& Snell (2004) highlighted that organizational capital reduce work costs and better serving customer by minimizing mistakes and processing information in efficiency way. moreover, the entire company's knowledge-system may lead to quickly and accurately solve customers' issues. On the basis of the above reasoning, we hypothesized the following:

H5. IC has a positive impact on $O P$.

H5a: human capital has a positive impact on $O P$.

H5b: Social capital has a positive impact on OP.

H5c: organization capital has a positive impact on OP.

\section{The mediating role of intellectual capital}

Some researchers have found that HPWSs affect organizational performance through improving intellectual capital ( Fu, Bosak, Rousseau, Morris, \& O'Regan, 2015). studies such as Youndt \& Snell, (2004) who indicated that different HR programs are related to the three forms of intellectual capital, which in turn related to organization performance. In the same way, Yang \& Lin (2009) and Snell \& Dean (1992) discussed that HR practices can assist companies performance by investing in building intangible IC, including skills and experiences.

HPWSs mission is to select and develop talents through practices. such practices were found to be positively related with the 
level of collective knowledge embedded in employees in the organization i.e. human capital (Takeuchi,2007), improving organizational capital (Fu, 2013; Wang \& Chen, 2013), enhance interpersonal communications as important resources, which can force organization performance (Jiang \& Liu, 2015). based on the above reasoning, this paper argued that having an effective bundle of HR practices ( as a coherent system ) that can accumulate human, social and organizational capital, may improve firm performance.

H6. IC mediate the relationship between HPWSs and OP.

H6a: human capital mediates the relationship between HPWSs and $O P$.

H6b: social capital mediates the relationship between HPWSs and $O P$.

H6c: organizational capital mediates the relationship between $H P W S$ s and $O P$.

As shown in figure I, the conceptual model hypothesized that there is a direct effect for HPWSs on intellectual capital ,and indirect effect on perceived organizational performance through the mediating role of human, social and organizational capital .

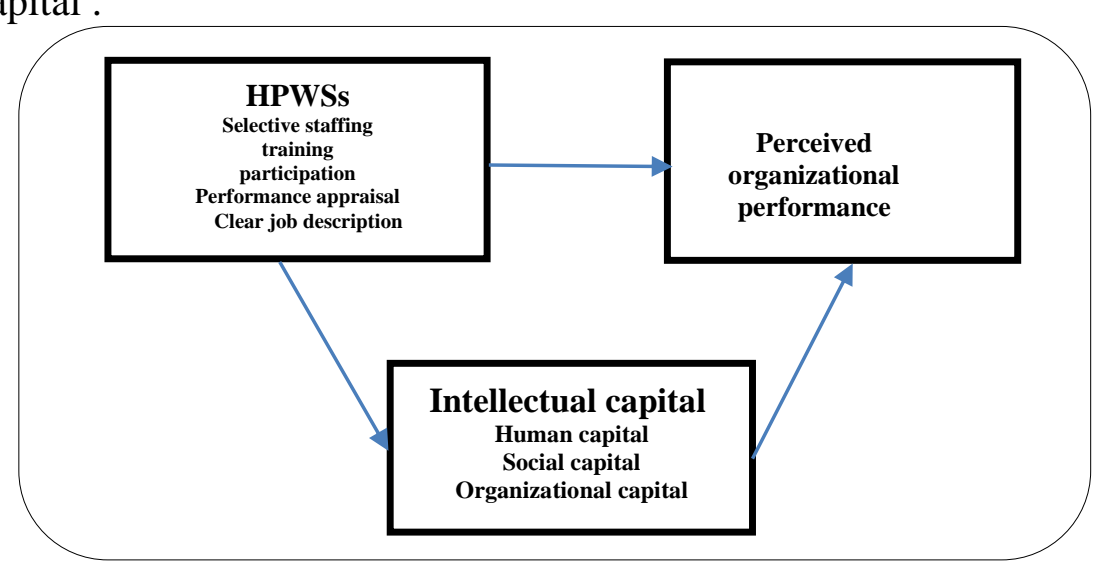

Figure (I)Conceptual Research model Source: author 


\section{Research method}

\section{Survey procedure and sample}

A questioner survey was employed to collect data for our field of interest. The questionnaire was distributed to the HR executives in Private hospitals located in Great Cairo, with 198 responses. The study first pre-test the questionnaire through various steps (Cavana, Delahaye, \& Sekeran, 2001). First, we test the face validity by viewing the measures used in the questionnaire, in order to assure that they cover the construct they intend to measure. Then , the final draft of the survey was distributed and verified through a sample of 30 healthcare's staff within the private hospitals. Finally, we assessed the reliability of the constructs using Cronbach's $\alpha$ coefficient(Table I). The $\alpha$ scores for all constructs used in our study exceeded the recommended cut-off score of 0.70 (Nunnally, Bernstein, \& Berge, 1967).

Table I: Results of the pilot study

\begin{tabular}{ccc}
\hline Variables & No. of items & Cronbach's $\boldsymbol{\alpha}$ \\
\hline HPWS & 16 & 0.749 \\
Human capital & 4 & 0.733 \\
Social capital & 3 & 0.801 \\
Organization capital & 4 & 0.853 \\
Organization performance & 7 & 0.843 \\
\hline
\end{tabular}

\section{Variables and Measurement}

this current research relies on perceptual measures in capturing all data needed for conducting the analysis.

$O P$ - dependent variable: Perceptual measures are usually used in capturing the organizational . The subjective methods- based on perceptions- have been applied in various empirical researches (Asiaei \& Jusoh, 2015; Muduli, 2015; Singh, 2004; 
Chand \& Katou, 2007). According to Zhu \& Bao (2015), it is more relevant to use subjective measure than the objective measure, in case of confidentiality and difficulties in obtaining information. OP was measured using an instrument developed by (Delaney \& Huselid, 1996), the variable was conceptualized by seven indicators relating to executive's perceptions of their hospital's performance over the past three years, compared with other hospitals similar to them. using a five-point Likert scale with anchors "significantly below average" and "significantly above average." This scale has been widely used in previous studies (Singh, 2004; Takeuchi, et al., 2007).

IC mediation variable: in order to capture IC level in the hospitals, the executives asked to express their opinions regarding a total 11 questions adopting from (Yang \& Lin, 2009). IC includes three components namely human, social, organizational capital, which were conceptualized with three or four indicators .the construct outlined in the survey by using the five-point Likert scale $(1=$ strongly disagree, $5=$ strongly agree $)$.

HPWSs- independent variable: HPWSs construct encompassed of 16 items adapting from (Michaelis, Wagner, \& Schweizer, 2015), express the five widely - used dimensions : selective staffing, participation, training, performance appraisal, and clear job description. a five-point Likert-type scale ranged from strongly disagree to strongly agree was used.

\section{Data Analysis and Results}

The study aims to measure and explain five main latent Constructs. first construct is High-performance work system (HPWS), which include five sub-latent constructs measured as follow:

- Training (TR): Train_1,Train_2 and Train_3.

- Participation (PA): Par_1,Par_2,Par_3 and Par_4

- Selection (SL):Sel_1,Sel_2 and Sel_3

- Performance appraisal (PR):Per_1,Per_2 and Per_3 
- Job description (JB):Job_1,Job_2 and Job_3

Second, thirds and fourth latent constructs related to intellectual capital:

- Human capital (HC), was measured by four observed variables HC_1, HC_2, HC_3 and HC_4.

- social capital (SC) was measured by three observed variables, SC_1,SC_2, and SC_3.

- organization capital (OC) was measured by four observed variables OC_1,OC_2,OC_3and OC_4.

Finally organization performance (OP) was measured by seven observed variables,OP_1,OP_2,OP_3,OP_4,OP_5,OP_6 and OP_7.

\section{The measurement model}

After assigning the relevant measured variables to each latent construct as indicated in (figure II). AMOS (v.22) was employed to assess both the measurement and structural models. The validity of the measurement model depends on the goodnessof-fit results that were employed in previous researches (ex. Chahal \& Jyoti, 2016). the overall model fit was indicated in the (table II) . 


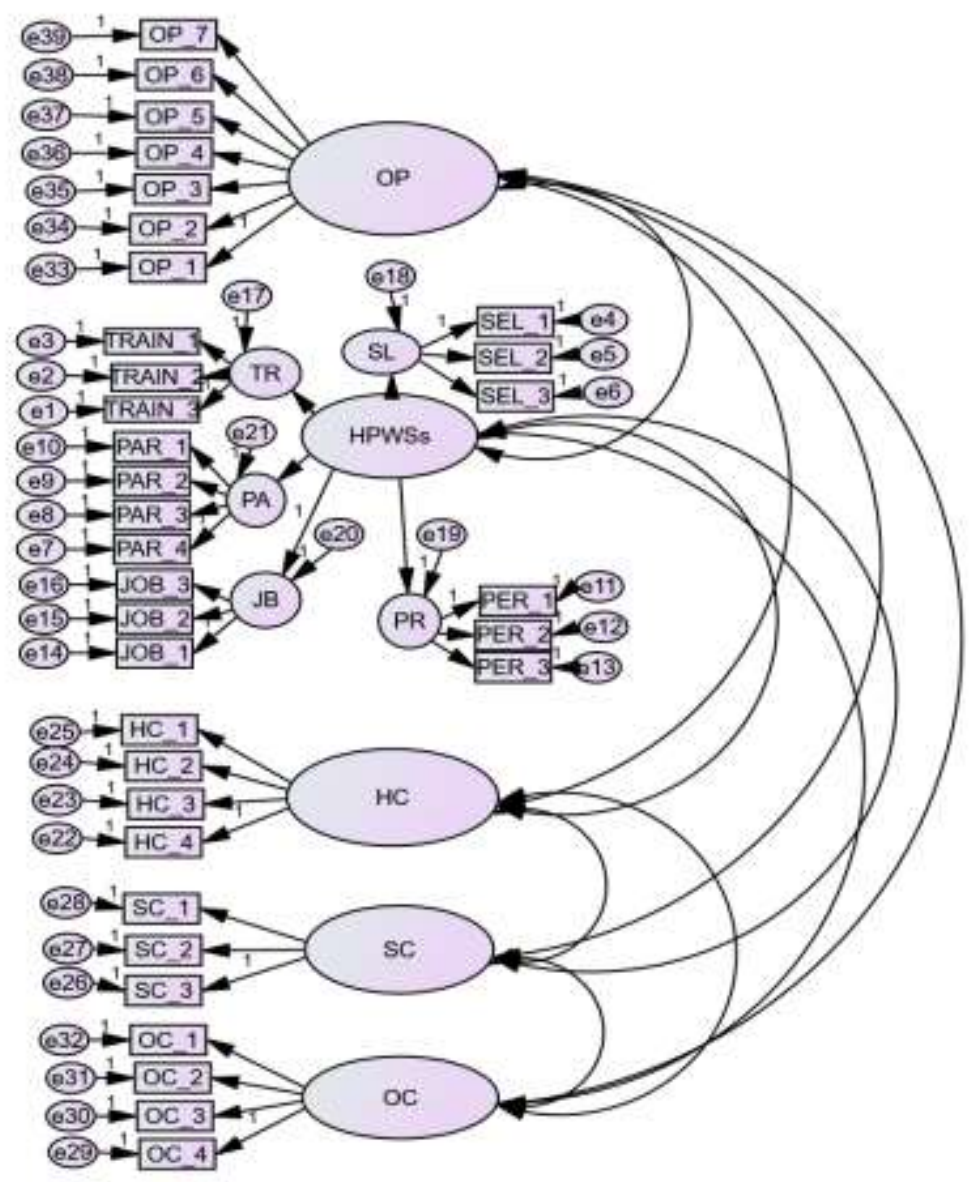

Figure II

The measurement model

Source : the author

Overall, the findings showed that the validation of the model is at acceptance levels. e.g. CMIN/DF is less than 5 . furthermore, GFI ,CFI and TLI are close to score 1 , which can indicate good model fit (Hair, et al., 2010) . additionally, the indicators loadings on their relevant variables is higher than 0.5. 
Considering the relatively small sample size and complexity of the model, we thought that the results are acceptable.

Table II Overall model goodness of fit for the measurement model.

\begin{tabular}{lc}
\hline Model fit index & SCORES \\
\hline Minimum sample discrepancy divided by degrees of & 1.42 \\
freedom (CMIN/DF) & 0.83 \\
Goodness-of-fit index (GFI) & 0.96 \\
Comparative fit index (CFI) & 0.05 \\
Root Mean Square Error of Approximation (RMSEA) & 0.88 \\
Normed fit index (NFI) & 0.95 \\
Tucker-Lewis coefficient (TLI) & \multicolumn{2}{c}{ Confirmatory factor analysis (CFA) was applied to assess the } \\
\hline \multicolumn{2}{c}{ construct validity for all the measures used. using both SPSS and } \\
AMOS. we evaluated the construct reliability by conducting \\
composite reliability (CR) and Cronbach's alpha test. the results were \\
at acceptance scores (Malhorta, 2010); CR for all construct > 0.8 and \\
greater than 0.7 for Cronbach's alpha test, see (Table III). Construct \\
validity can be tested through the estimation of each measure's \\
convergent, discriminate validity and factor loading for each item. \\
convergent, and discriminate validity were used widely in various \\
studies (e.g. Asiaei \& Jusoh, 2015; Chahal \& Jyoti, 2016).
\end{tabular}

Table III Results of confirmatory factor analysis

\begin{tabular}{|c|c|c|c|c|c|c|c|c|}
\hline & $\begin{array}{c}\text { Cronbac } \\
\text { h's } \alpha\end{array}$ & CR & AVE & HPWSs & HC & SC & OC & OP \\
\hline HPWS & 0.957 & 0.979 & 0.904 & 0.951 & & & & \\
\hline HC & 0.921 & 0.923 & 0.751 & $0.651^{*}$ & 0.866 & & & \\
\hline SC & 0.793 & 0.797 & 0.569 & $0.516^{*}$ & $0.679^{*}$ & 0.754 & & \\
\hline OC & 0.898 & 0.901 & 0.697 & -0.001 & 0.087 & 0.022 & 0.835 & \\
\hline Op & 0.942 & 0.942 & 0.698 & $0.538^{*}$ & $0.830^{*}$ & $0.624^{*}$ & $0.091^{*}$ & 0.836 \\
\hline
\end{tabular}

Note :* correlations are significant at $\mathbf{p}<\mathbf{0 . 0 0 1}$

Italic bold: square root of AVE.

For convergent validity, the average variance extracted (AVE) scores have their ranges between 0.697 and 0.904. In addition, Discriminate validity was tested by comparing the 
square root of AVE for each construct with the correlations with other constructs (fornell \& larcker, 1981) (Hair, Anderson, Babin, \& Black, 2010). the results indicate that AVE for the constructs was higher than their multiple correlations with the rest of the constructs, which support the discriminate validity for the constructs.

\section{The structure model}

To answer the research questions, Structure equation model was used to empirically test the proposed model. There were two main steps that was used.

An initial step included measuring the SEM model fit (Table V). According to the indices presented in the table below, all extracted fit values are within acceptable levels.

Table V: Overall model goodness of fit for the structure model.

\begin{tabular}{ll}
\hline Model fit index & SCORES \\
\hline Minimum sample discrepancy divided by degrees of & 1.50 \\
freedom (CMIN/DF) & \\
Goodness-of-fit index (GFI) & 0.82 \\
Comparative fit index (CFI) & 0.95 \\
Root Mean Square Error of Approximation (RMSEA) & 0.05 \\
Normed fit index (NFI) & 0.86 \\
Tucker-Lewis coefficient (TLI) & 0.94 \\
\hline
\end{tabular}

The Second step ( testing the hypotheses ) included extracting the path coefficients for the direct and indirect effects.

The correlation between variables was extracted as shown in Table III. the interrelations between intellectual capital dimensions were significant except for organizational capital. Additionally, OC wasn't correlated significantly with any other variable. That's mean, in our sector of analysis ( i.e private health care organizations), organizations don't give much attention to $\mathrm{OC}$, they depending on their available talented 
people (i.e human capital) and their internal network (i.e . social capital) for achieving the reputation they need.

Table (VI) presents the standardized coefficients for direct and indirect effects. The hypotheses $\mathrm{H} 1$ till $\mathrm{H} 3$ examining the impact of HPWSs on Intellectual capital's dimensions . according to the results ; $\mathrm{H} 1$ and $\mathrm{H} 3$ were supported, which means that HPWSs as a bundle could create IC in the healthcare sector for both Human and social capital, whereas H2 wasn't supported.

The standardized coefficients for our direct relationships revealed that HPWSs significantly affect organizational performance. (i.e H4 was supported). In the literature, prior empirical evidence supports these results (example Takeuchi, et al., 2007; Way, 2002).

The fifth hypothesis proposed the positive relationship between intellectual capital's dimensions and OP . according to the results it was partially supported. It has seen that only human and social capital improve hospital's performance.it is worth to be mentioned that our results agreed with the prior studies that confirmed that relationship (Asiaei \& Jusoh, 2015;Inkinen, 2015).

At last, for examining the indirect effect we followed (Baron \& Kenny, 1986) suggestions for the three-step approach. The standardized Coefficients and $p$-values for indirect relationships between HPWSs and OP were significant Table (VI) which means that H5 was also partially supported in our analysis . 
Table VI. Path coefficients for Direct and Indirect Effects.

\begin{tabular}{llr}
\hline Path & Estimate & Remarks \\
\hline HPWS $\rightarrow$ OP & $0.583^{* *}$ & Accepted \\
HPWS $\rightarrow$ HC & $0.686^{* *}$ & Accepted \\
HPWS $\rightarrow$ OC & $0.011(\mathrm{~ns})$ & Not accepted \\
HPWS $\rightarrow$ SC & $0.555^{* *}$ & Accepted \\
HC $\rightarrow$ OP & $0.790^{* *}$ & Accepted \\
SC $\rightarrow$ OP & $0.172^{* *}$ & Accepted \\
OC $\rightarrow$ OP & $0.009(\mathrm{~ns})$ & Not Accepted \\
HPWS $\rightarrow$ HC $\rightarrow$ OP & $0.542^{*}$ & Accepted \\
HPWS $\rightarrow$ SC $\rightarrow$ OP & $0.241^{*}$ & Accepted
\end{tabular}

NOTES: ${ }^{* *} p<0.01, * p<0.05$

Discussion, Implications, and limitations.

This paper explores the critical linkage between HPWSs system and OP through a mediating model. The results of the SEM approach provide some empirical evidence to support the hypothesized model within the Private health care organizations. First, Data analysis confirms that HPWSs contribute to the accumulation of both Human and Social Capital. Second, HPWSs, Human and Social capital associated with perceived OP. Third, HPWSs is significantly associated with OP through the mediating role of human and social capital. In fact, the paper found no significant evidence for Organizational capital in the model. a Reason of this result may be related to the non-ability of the private hospitals to institutionalize a knowledge management system.

The theoretical contribution of this paper is testing of a mediating model, which intervene between the best HRM practices, multi-dimensions for intellectual capital, and perceived OP.With respect to the managerial implications, this study has several important messages. First, HPWSs is suitable for organizations with high- skilled professionals in order to increase their performance. however, the mediating role of Human capital in the HPWSs-OP relationship suggests that implementing a well-designed HPWSs is relevant in shaping a 
highly qualified and skilled healthcare staff who can foster their hospital's performance through accumulating a knowledge-intensive base embodied in their humans and relations. second, it is better to enforce human capital within small hospitals than larger ones in order to achieve better outcomes. investing in doctors, nurses and other hospital staff may result in achieving better service performance.

The enforcement activities begin with the recruitment and selecting process in which HR manager should attract highly skilled, talented and motivated human resources. Moreover, for current staff, training programs, such as on-thejob experience, will result in identifying problems, correcting dysfunctions and developing the employees' knowledge. performance appraisal is another activity that ensures wellexpected outcomes through taking the correct actions for staff with low performance. concerning with customer's suggestions and comments about recruited and selected staff would be a sign for well- developed human capital activities ( Lin, Huang, Du, \& Lin, 2010).

As well, HPWSs helps in facilitating social relations among staff by improving the opportunity, motivation, and ability to assess one another's knowledge. Employment practices such as training programs and participation in decision making support freely knowledge sharing between different parties.

However, the findings of this study are subject to a number of limitations. The main limitation involves the fact that our data collection depends upon the management view, ignoring the employee's perceptions on best HRM practices. A second important limitation includes the use of subjective performance indicators. 
References

Aghazadeh, S.-M., \& Seyedian, M. (2004). The highperformance work system: is it worth using? team Performance Management: An International Journal, 10(3/4), 60 - 64.

Agostini, L., Nosella , A., \& Filippini, R. (2017). Does intellectual capital allow improving innovation performance? A quantitative analysis in the SME context. Journal of Intellectual Capital, 18(2), 400-418.

Alipour, M. (2012). The effect of intellectual capital on firm performance: an investigation of Iran insurance companies. measuring business excellence, 16(1), 55-63.

Andreeva , T., \& Garanina , T. (2016). "Do all elements of intellectual capital matter for organizational performance? Evidence from Russian context". Journal of Intellectual Capital, 17(2), .397-412.

Arthur, J. \& Yang, J. (2016). H ow top management HR beliefs and values affect high- performance work systems adoption and implemintation effectiveness. Human Resource Management, 55(2), p. 413-435.

Asiaei, K., \& Jusoh, R. (2015). A multidimensional view of intellectual capital: the impact on organizational Performance. Management Decision, 53(3), 668 - 697.

Baron, R., \& Kenny, D. (1986). he moderator-mediator variable distinction in social psychological research: Conceptual, strategic, and statistical considerations. Journal of Personality and Social, 51, 1173-1182.

Bontis, N., Keow , W., \& Richardson , S. (2000). Intellectual capital and business performance in Malaysian industries. Journal of Intellectual Capital, 1(1), 85-100.

Bontis, N., Crosson, M., \& Hulland, j. (2002). MANAGING AN ORGANIZATIONAL LEARNING SYSTEM BY 
ALIGNING STOCKS AND FLOWS. Journal of Management Studies, 39(4), 437-467.

Boxall, P., \& Macky, K. (2009). Research and theory on highperformance work systems: progressing the high involvement stream. human resource management journal, 19(1), 3-23.

Brooking, A. (1996). Intellectual capital - core asset for the third millennium enterprise. london: international Thomson Business Press.

Cafferkey, K. \& Dundon, T., 2015. Explaining the black box: HPWS and organisational climate. Personnel Review, 44(5), pp. $666-688$.

Cavana, R., Delahaye, B., \& Sekeran, U. (2001). Applied Business Research: Qualitative and Quantitative Methods. Australia: John Wiley \& Sons.

Chen, M.-C., Cheng, S.-J., \& Hwang, Y. (2005). An empirical investigation of the relationship between intellectual capital and firms' market value and financial performance. Journal of Intellectual Capital, 6(2), 159-176.

Chahal, H., \& Jyoti, J. (2016). The Effect of Perceived High performance Human Resource Practices on Business Performance:. Global Business Review, 17(3), 107-132.

Chand, M., \& Katou, A. (2007). The impact of HRM practices on organisational performance in the Indian hotel industry. Employee Relations, 29(6), 576 - 594.

Chia, P. L., Yahya, K. K., \& Yean, T. F. (2016). Organizational Social Capital and Commitment-Based HR Practices as the Determining Factors of Organizational Performance. International Journal of Business and Management, 11(6), 129-144.

Delaney, J. T., \& Huselid, M. A. (1996). the impact of human resource management practices on perceptions of 
organizational performance. Academy of Management Journal, 39(4), 949-969.

Dženopoljac , V., Janoševic, S., \& Bontis, N. (2016). intellectual capital and financial performance in the Serbian ICT industry. Journal of Intellectual Capital, 17(2), 373-396.

fornell, c., \& larcker, D. (1981). Evaluating structural equation models with unobservable variables and measurement erroR. Journal of Marketing Research, 18(1), 39-50.

$\mathrm{Fu}$, N. (2013). exploring the impact of high performance work systems in professional service firms: a practicesresources-uses performance approach. Consulting Psychology Journal: Practice and Research, 65(3), 240257.

Fu, N. F., Bosak, P. C., Rousseau, D. M., Morris, T., \& O'Regan, P. (2015). High-Performance Work Systems in Professional Service Firms: Examining the Practices-Resources-Uses-Performance Linkage. Human Resource Management.

García-Chas, Neira-Fontela, E., \& Varela-Neira, C. (2016). High-performance work systems and job satisfaction: a multilevel model. Journal of Managerial Psychology, 31(2), 451 - 466.

Gogan, L., Artene, A., Sarca, I., \& Draghici , A. (2016). The Impact of Intellectual Capital on Organizational Performance . Procedia - Social and Behavioral Sciences , 221, $194-202$.

Hair, J., Anderson, I., Babin, B., \& Black, W. (2010). Multivariate data analysis: A global perspective (Vol. 7). Upper Saddle River, NJ: Pearson.

Hall , R. (1992). The Strategic Analysis of Intangible Resources. Strategic Management Journal, 13(2), 135-144 .

Huselid , M. (1995). The Impact of Human Resource Management Practices on Turnover, Productivity, and 
Corporate Financial Performance. The Academy of Management Journal, 38(3), 635-672.

Ingvaldsen, J., Johansen, T. S., \& Aarlott, M. M. (2014). Emergent HPWS: why HRM may not be needed to build a high-performance work system. Team Performance Management, 20(7/8), 294-306.

Inkinen, H. (2015). Review of empirical research on intellectual capital and firm performance. Journal of Intellectual Capital, 16(3), 518 - 565.

Jiang, J. y., \& Liu, C.-W. (2015). High performance work systems and organizational effectiveness: The mediating role of social capital. Human Resource Management Review, 25, 126-137.

Kalkan, A., Bozkurt, Ö., \& Arman, M. (2014). The impacts of intellectual capital, innovation and organizational strategy on firm performance. Procedia - Social and Behavioral Sciences, 150, $700-707$.

Kalmi, P. \& Kauhanen, A., 2008. Workplace Innovations and Employee Outcomes. Industrial Relations, 47(3), pp. 432-459.

Leana, C. R., \& Buren, H. J. (1999). Organizational Social Capital and Employment Practices. The Academy of Management Review, 24(3), 538-555.

Liao, H., Toya, K., Lepak, D. P., \& Hong, Y. (2009). Do They See Eye to Eye? Management and Employee Perspectives of High-Performance Work Systems and Influence Processes on Service Quality. Journal of Applied Psychology, 94(2), 371-391.

Lin, L.-S., Huang, I.-C., Du, P.-L., \& Lin, T.-F. (2010). Human capital disclosure and organizational performance: The moderating effects of knowledge intensity and organizational size. Management Decision, 50(10), .1790-1799. 
Malhorta, N. (2010). Markeing research : an applied orientation. N.J: Pearson.

Michaelis, B., Wagner, J., \& Schweizer, L. (2015). Knowledge as a key in the relationship between high-performance work systems and workforce productivity. Journal of Business Research, 68, 1035-1044.

Muduli, A. (2015). High performance work system, HRD climate and organisational performance: an empirical study. European Journal of Training and Development, 39(3), 239 - 257.

Nahapiet, J., \& Ghoshal, S. (1998). Social capital, intellectual capital, and the organizational advantage. Academy of management review , 23(2), 242-266.

Nonaka, I. (1994). A dynamic theory of organizational knowledge creation. organization science, 5(1), 14-38.

Nunnally, J., Bernstein, I., \& Berge, J. (1967). Psychometric Theory (Vol. 226). New York, NY.: McGraw-Hill.

Qiao, K., Wang, X., \& Wei, L.-Q. (2015). Determinants of highperformance work systems in small and medium-sized private enterprises in China. Asia Pacific Journal of Human Resources, 53, 185-203.

Riahi-Belkaoui, A. (2003). ntellectual capital and firm performance of US multinational firms: A study of the resource-based and stakeholder views. Journal of Intellectual Capital, 4(2), 215-226.

Rossi, C., Cricelli, L., Grimaldi, M., \& Greco, M. (2016). The strategic assessment of intellectual capital assets: An application within Terradue Srl. Journal of Business research, 69(5), 1598-1603.

Scafarto, V., Ricci, F., \& Scafarto, F. (2016). intellectual capital and firm performance in the global agribusiness industry: The moderating role of human capital. journal of Intellectual Capital, 17(3), 530-552. 
Shin, D., \& Konrad, A. m. (2014). Causality Between HighPerformance Work Systems and Organizational Performance. Journal of Management, 1-25.

Singh, K. (2004). Impact of HR practices on perceived firm performance in INDIA. Asia Pacific Journal of Human Resources, 42(3), 301-317.

Snell, S. A., \& Dean, J. W. (1992). Integrated Manufacturing and Human Resource Management: A Human Capital Perspective. The Academy of Management Journal, 35(3), 467-504.

Stewart, T. (1997). Intellectual Capital. The New Wealth of Organizations,. New York: Doubleday.

SUBRAMANIAM, M., \& YOUNDT, M. A. (2005). THE INFLUENCE OF INTELLECTUAL CAPITAL ON THE TYPES OF INNOVATIVE CAPABILITIES. Academy of Management Journal, 48(3), 450-463.

Takeuchi, R., Lepak, D., Wang, H., \& Takeuchi, K. (2007). An Empirical Examination of the Mechanisms Mediating Between HighPerformance Work Systems and the Performance of Japanese. Journal of Applied Psychology, 92(4), 1069-1083.

Torre, E. D., \& Solari, L. (2011). High performance work systems, technological innovations and firm performance in SME:evidences from Italy. international journal of Entrepreneurial Venturing, 3(4), 375-389.

Ugheoke, S. O., Al-Rawas, N. M., Isa, M. F., \& Wan, W. S. (2015). Implementation of High Performance Work System in Public Organizations: Implication to Organizational Performance. Asian Social Science, 11(22), 139-148.

Wallner, T., Menrad, M., \& Thurner, S. (2012). EMPOWERMENT IN HIGH PERFORMANCE WORK SYSTEMS FROM A SYSTEMS THEORY 
PERSPECTIVE. management, knowledge and learning international conference, 349-352.

Wang, D., \& Chen, S. (2013). Does intellectual capital matter?High-performance work systems and bilateral innovative capabilities. International Journal of Manpower, 34(8), 861-879.

Wang, Z., Wang, N., \& Liang, H. (2014). Knowledge sharing, intellectual capital and firm performance. Management Decision, 52(2), 230 - 258.

Way, S. A. (2002). High Performance Work Systems and Intermediate Indicators of Firm Performance Within the US Small Business Sector. Journal of Management, 28(6), 765-785.

Yang, c.-c., \& Lin, c. (2009). does intellectual capital mediate the relationship between HRM and organizational performance? perspective of a healthcare industry in Taiwan. The international journal of human resource management, 20(9), 1965-1984.

Youndt, M. A., \& Snell, S. A. (2004). Human Resource Configurations, Intellectual Capital, and Organizational Performance. Journal of Managerial Issues, 16(3), 337360.

Zhu, K., \& Bao, H. (2015). High-performance human resource management and firm performance. Industrial Management \& Data Systems, 115(2), 353 - 382. 